\title{
UJI KELARUTAN Si TERSEDIA PADA TRASS BAKAR DAN NON BAKAR
}

\section{Experiment of Silica Solubility Availability on Fuel and Non Fuel Trass}

\section{Mirawanty Amin ${ }^{1)^{*}}$, Budi Nugroho²) dan Dyah Tjahyandari Suryaningtyas')}

1) Program Studi Ilmu Tanah, Sekolah Pascasarjana IPB University, Kampus IPB Dramaga Bogor 16680 2) Departemen Ilmu Tanah dan Sumbedaya Lahan, Fakultas Pertanian IPB University, Jl. Meranti Kampus IPB Dramaga Bogor 16680

\begin{abstract}
This research was conducted to determine the available Si between burned trass and unburned trass, also to determine the best formula to be used as silica fertilizer. This research was conducted at the Laboratory of Soil Chemistry and Fertility, Department of Soil Science and Land Resources, Faculty of Agriculture, IPB University. The experimental design was the split plot with the main plot consisted of burned trass and unburned trass, and the sub plot consisted of combination dosage of trass and $\mathrm{CaCO}_{3}$, those were $100 \%$ trass, $83.33 \%$ trass $+16.67 \mathrm{CaCO}_{3}, 66.67 . \%$ trass $+33.33 \% \mathrm{CaCO}_{3}$, each treatment was replicated three times, resulting 18 experiment units. The result showed that the burned trass showed the highest available Si compared to unburned trass. The combination of $83 \%$ trass $+17 \% \mathrm{CaCO}_{3}$ showed the highest available Si $\theta$ those were 120.02 ppm, $72.67 \mathrm{ppm}$ and $53.43 \mathrm{ppm}$, respectively with extractant of ammonium acetate $\mathrm{pH} 4.8,0.5 \mathrm{M} \mathrm{HCl}$ and $\mathrm{H}_{2} \mathrm{O}$.
\end{abstract}

Keywords: $\mathrm{CaCO}_{3}$, fertilizer, silica, trass

\section{ABSTRAK}

Penelitian ini dilakukan untuk mempelajari kelarutan Si tersedia antara trass bakar dan non bakar dan penentuan formula terbaik untuk dijadikan sebagai pupuk silika. Penelitian ini dilakukan di Laboratorium Kimia dan Kesuburan Tanah, Departemen Ilmu Tanah dan Sumberdaya Lahan, Institut Pertanian Bogor. Rancangan Percobaan yang dilakukan adalah split plot dengan petak utama terdiri dari trass bakar dan non bakar, dan anak petak terdiri dari dosis trass yang dikombinasikan dengan $\mathrm{CaCO}_{3}$ yaitu $100 \%$ trass, $83.33 \%$ trass $+16.67 \mathrm{CaCO}_{3}, 66.67 \%$ trass $+33.33 \% \mathrm{CaCO}_{3}$, masing-masing perlakuan diulang sebanyak tiga kali, sehingga total satuan percobaan ada 18. Hasil penelitian menunjukkan bahwa trass bakar menunjukkan hasil kelarutan silika tersedia tertinggi dibandingkan trass non bakar. Kombinasi $83 \%$ trass $+17 \% \mathrm{CaCO}_{3}$ menunjukkan Si tersedia tertinggi yaitu

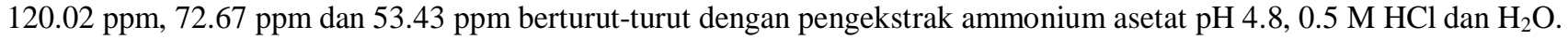

Kata kunci: $\mathrm{CaCO}_{3}$, pupuk, silika, trass,

\section{PENDAHULUAN}

Silika adalah unsur kedua terbanyak setelah oksigen dalam tanah dan memiliki manfaat pada beberapa jenis tanaman (Ashtiani et al., 2012). Meskipun Si tidak digolongkan sebagai unsur hara essensial (Hayasaka et al., 2008; Marchner, 1995; Eipstein, 1994), namun pada beberapa tanaman silika diperlukan dalam jumlah yang banyak seperti unsur hara makro (Kamenidou et al., 2009; Eipstein, 1994).

Menurut Datnoft et al. (1997) Si dapat meningkatkan ketahanan tanaman terhadap cekaman (stress) abiotik, mengurangi toksisitas logam dan meningkatkan aktivitas enzim. Di sisi lain, dengan penambahan silika dapat meningkatkan ketahanan tanaman terhadap hama dan penyakit (Zellner et al., 2011; Van Bockhaven et al., 2013; Liang et al., 2015; Sakr et al., 2016). Yukamgo dan Yuwono (2007) menyatakan bahwa Si dalam tanah dapat meningkatkan ketersediaan $\mathrm{P}$ dan mengurangi aktivitas logam beracun seperti Al, Fe dan Mn. Oleh karena Si dibutuhkan dalam jumlah yang banyak pada beberapa tanaman dan terbukti dapat meningkatkan produktivitas tanaman (Epstein, 1994; Keeping et al., 2009; Meyer dan Keeping, 2005; Snyder et al., 2007), sehingga aplikasi pupuk atau sumber Si sangat diperlukan.
Salah satu sumber silika yang dapat dijadikan sebagai pupuk adalah trass. Trass merupakan salah satu bahan alam yang banyak mengandung oksida silika, sehingga berpeluang untuk dimanfaatkan sebagai pupuk Si. Trass merupakan tufa terlapukkan yang memiliki kandungan kalsium selain silika. Kandungan kalsium dan silika pada trass dapat digunakan untuk pengapuran serta sebagai bahan pupuk silika. Saat ini penelitian mengenai trass sebagai sumber silika masih sangat sedikit. Oleh karena itu, perlu dilakukan penelitian mengenai kelarutan trass sebagai sumber silika dengan cara dibakar dan dibandingkan dengan tidak dibakar.

\section{BAHAN DAN METODE}

Bahan yang digunakan dalam penelitian ini adalah trass, $\mathrm{CaCO}_{3}$ dan bahan-bahan kimia yang digunakan untuk analisis di laboratorium. Alat-alat yang digunakan adalah tanur, wadah liat, alat tulis, timbangan, waterbath dan spectrophotometer.

Rancangan percobaan yang digunakan adalah split plot (Split Plot Design) dengan petak utama trass bakar dan non bakar, sedangkan anak petak adalah tiga dosis perlakuan kombinasi trass dan $\mathrm{CaCO}_{3}$ (Tabel 1); masing- 
masing perlakuan diulang tiga kali sehingga total terdapat 18 satuan percobaan.

Tabel 1. Dosis trass bakar dan non bakar

\begin{tabular}{ccc}
\hline Kode Perlakuan & Trass $(\%)$ & $\mathrm{CaCO}_{3}(\%)$ \\
\hline $\mathrm{Ta}_{1}$ (trass bakar) & 100 & 0 \\
$\mathrm{Ta}_{2}$ (trass bakar) & 83.33 & 16.67 \\
$\mathrm{Ta}_{3}$ (trass bakar) & 66.67 & 33.33 \\
$\mathrm{~Tb}_{1}$ (non bakar) & 100 & 0 \\
$\mathrm{~Tb}_{2}$ (non bakar) & 83.33 & 16.67 \\
$\mathrm{~Tb}_{3}$ (non bakar) & 66.67 & 33.33 \\
\hline
\end{tabular}

Sebelum digunakan untuk penelitian, maka trass dikeringudarakan terlebih dahulu, lalu dihaluskan dengan cara ditumbuk dan disaring dengan ukuran 100 mesh. Untuk memperoleh trass bakar, maka trass yang sudah disaring, ditimbang dan ditambahkan $\mathrm{CaCO}_{3}$ sesuai dengan dosis perlakuan, selanjutnya dipanaskan dalam tanur pada suhu $700{ }^{\circ} \mathrm{C}$ selama 2 jam. Trass yang sudah dibakar tersebut kemudian didinginkan dan ditambahkan aquades. Setelah itu dipanaskan kembali dalam tanur pada suhu $500{ }^{\circ} \mathrm{C}$ selama 1 jam. Setelah itu dilakukan analisis kelarutan $\mathrm{Si}$ tersedia dengan menggunakan tiga pengekstrak, yaitu $\mathrm{NH}_{4} \mathrm{OAc} \mathrm{pH} 4.8,0.5 \mathrm{M} \mathrm{HCl}$ dan $\mathrm{H}_{2} \mathrm{O}$.

\section{HASIL DAN PEMBAHASAN}

Berdasarkan hasil analisis statistik, dosis kombinasi trass dan $\mathrm{CaCO}_{3}$ berpengaruh nyata terhadap kandungan $\mathrm{Si}$ tersedia tanah yang diuji dengan ketiga pengekstrak (Tabel 2).

Tabel 2. Hasil analisis Si tersedia pada trass bakar dan non bakar

\begin{tabular}{cccc}
\hline Perlakuan & $\mathrm{HCl} 0.5 \mathrm{M}$ & $\mathrm{NH}_{4} \mathrm{OAc} \mathrm{pH} 4.8$ & $\mathrm{H}_{2} \mathrm{O}$ \\
\hline $\mathrm{Ta}_{1}$ & $30.55 \mathrm{c}$ & $52.32 \mathrm{~d}$ & $20.82 \mathrm{~b}$ \\
$\mathrm{Ta}_{2}$ & $72.62 \mathrm{e}$ & $120.02 \mathrm{f}$ & $52.43 \mathrm{e}$ \\
$\mathrm{Ta}_{3}$ & $65.68 \mathrm{a}$ & $91.76 \mathrm{e}$ & $30.97 \mathrm{~d}$ \\
$\mathrm{~Tb}_{1}$ & $29.84 \mathrm{c}$ & $40.34 \mathrm{c}$ & $28.08 \mathrm{c}$ \\
$\mathrm{Tb}_{2}$ & $27.33 \mathrm{~b}$ & $37.17 \mathrm{~b}$ & $27.47 \mathrm{c}$ \\
$\mathrm{Tb}_{3}$ & $23.88 \mathrm{a}$ & $31.75 \mathrm{a}$ & $17.81 \mathrm{a}$
\end{tabular}

Keterangan: angka yang diikuti oleh huruf yang sama pada kolom yang sama menunjukkan tidak berbeda nyata pada taraf $\alpha=5 \%$ dengan Uji lanjut Duncan

Hasil uji Duncan menunjukkan bahwa bahwa trass yang dibakar memiliki kelarutan yang lebih tinggi dibandingkan trass non bakar. Perlakuan $\mathrm{Ta}_{2}$ yang merupakan campuran $83.33 \%$ trass bakar: $16.67 \% \mathrm{CaCO}_{3}$ menunjukkan Si tersedia tertinggi pada ketiga pengekstrak. Hasil analisis $\mathrm{Si}$ tersedia pada trass bakar, awalnya mengalami kenaikan dari $\mathrm{Ta}_{1}$ ke $\mathrm{Ta}_{2}$ sebesar $42.07 \mathrm{ppm}$ (137.71\%) dengan pengekstrak $\mathrm{HCl} 0.5 \mathrm{M}, 51.24 \mathrm{ppm}$ (129.4\%) dengan pengekstrak $\mathrm{NH}_{4} \mathrm{OAc} \mathrm{pH} 4.8,31.61 \mathrm{ppm}$ (151.83\%) dengan pengekstrak $\mathrm{H}_{2} \mathrm{O}$. Namun, dari $\mathrm{Ta}_{2} \mathrm{ke}$ $\mathrm{Ta}_{3} \mathrm{Si}$ tersedia mengalami penurunan yaitu $6.94 \mathrm{ppm}$ $(9.56 \%)$ dengan pengekstrak $\mathrm{HCl} 0.5 \mathrm{M}, 28.26 \mathrm{ppm}$ (23.54\%) dengan pengekstrak $\mathrm{NH}_{4} \mathrm{OAc} \mathrm{pH} 4.8$ dan 21.46 ppm $(40.93 \%)$ dengan pengekstrak $\mathrm{H}_{2} \mathrm{O}$.

Pada $\mathrm{Ta}_{2}$ sudah mencapai maksimum, sehingga pada $\mathrm{Ta}_{3}$ mengalami penurunan karena sudah mencapai maksimum kandungan $\mathrm{Si}$ tersedia pada $\mathrm{Ta}_{2}$, hal tersebut sesuai dengan Hukum Minimum dimana penambahan unsur yang dilakukan di atas titik batas tidak dapat membantu, karena unsur yang lain menjadi faktor pembatas (Munawar, 2011).
Pada trass non bakar, hasil analisis Si tersedia tertinggi didapatkan pada $\mathrm{Tb}_{1}$ yaitu $100 \%$ trass. Selanjutnya, semakin menurun dosis trass dan semakin meningkat dosis $\mathrm{CaCO}_{3}$ yang ditambahkan, maka $\mathrm{Si}$ tersedia dalam tanah juga semakin menurun.

Pada penelitian ini dilakukan pembakaran sebanyak dua kali yaitu $700{ }^{\circ} \mathrm{C}$ dan $500{ }^{\circ} \mathrm{C}$. Hal tersebut mengacu pada hasil penelitian yang telah dilakukan oleh Pratono et al. (2013) bahwa semakin tinggi temperatur maka semakin besar kelarutan silika dalam air. Dengan dikombinasikan trass dan $\mathrm{CaCO}_{3}$ dan dipanaskan dalam tanur akan menghasilkan reaksi seperti berikut:

$$
\mathrm{CaCO}_{3} \rightarrow \mathrm{CaO}+\mathrm{CO}_{2}
$$

Kemudian ditambahkan $\mathrm{H}_{2} \mathrm{O}$, akan menghasilkan reaksi dibawah ini:

$$
\mathrm{CaO}+\mathrm{H}_{2} \mathrm{O} \rightarrow \mathrm{Ca}(\mathrm{OH})_{2}
$$

Senyawa $\mathrm{Ca}(\mathrm{OH})_{2}$ yang dihasilkan dari reaksi kedua akan memberikan sifat basa (Refnita et al., 2012) dan kelarutan silika akan meningkat, dimana $\mathrm{Si}(\mathrm{OH})_{4}$ atau asam monosilikat merupakan bentuk silika di dalam tanah yang dapat diserap oleh hampir semua tanaman. Asam monosilikat $\left(\mathrm{H}_{4} \mathrm{SiO}_{4}\right.$ atau $\left.\mathrm{Si}(\mathrm{OH})_{4}\right)$ merupakan produk dari pelarutan mineral-mineral kaya Si (Lindsay, 1979).

Jumlah ketersediaan $\mathrm{H}_{4} \mathrm{SiO}_{4}$ atau $\mathrm{Si}(\mathrm{OH})_{4}$ di dalam tanah sangat bergantung pada $\mathrm{pH}$ dan kandungan $\mathrm{Al}$ dan $\mathrm{Fe}$ dari Tanah (Szulc et al., 2015). Dengan pH tanah yang lebih tinggi, jumlah $\mathrm{H}_{4} \mathrm{SiO}_{4}$ meningkat dalam tanah. Maksimum ketersediaan $\mathrm{H}_{4} \mathrm{SiO}_{4}$ pada tanah terjadi pada $\mathrm{pH}$ 6.5-8.5, sedangkan pada tanah yang memiliki pH 5-6 atau lebih rendah, seringkali tanaman kekurangan Si karena adanya pencucian $\mathrm{H}_{4} \mathrm{SiO}_{4}$ (Frings et al., 2014). Oleh karena itu, dengan adanya trass yang diberi perlakuan dengan pembakaran pada tanur dapat meningkatkan kelarutan silika tersedia dengan meningkatnya $\mathrm{pH}$.

Silika yang dihasilkan dari trass $+\mathrm{CaCO}_{3}$ mampu melepaskan anion $\left(\mathrm{OH}^{-}\right)$ke dalam larutan, menyebabkan $\mathrm{pH}$ menjadi meningkat. Sesuai dengan pernyataan Summer dan Farina (1986) bahwa reaksi silikat di dalam tanah sama seperti yang terjadi pada proses pengapuran dapat meningkatkan $\mathrm{pH}$ tanah.

\section{SIMPULAN}

Pada percobaan yang telah dilakukan, $\mathrm{Ta}_{2}(83.33$ trass+16.67 $\mathrm{CaCO}_{3}$ ) merupakan formula terbaik yang dapat dijadikan sebagai pupuk silika karena memiliki kandungan Si tersedia yang paling tinggi berdasarkan hasil uji dengan tiga ekstrak yaitu $120.02 \mathrm{ppm}$ dengan ammonoium asetat $\mathrm{pH} 4.8 ; 72.67 \mathrm{ppm} 0.5 \mathrm{M} \mathrm{HCl}$ dan 52.43 ppm $\mathrm{H}_{2} \mathrm{O}$.

\section{DAFTAR PUSTAKA}

Ashtiani, F.A., J. Kadir, A. Nasehi, R. Hashemian and H. Sajili. 2002. Effect of silicon on rice blast disease. Pertanika. J. Trop. Agric. Sci., 35(S): 1-12.

Datnoff, L. E., C.W. Deren and G.H. Snyden. 1997. Silicon fertilization for disease management of rice in Florida. Crop Protection, 16(6), 525-531 
Epstein, E. 1994. The anomaly of silicon in plant biology. Proceedings of the National Academy of Sciences, 91(1): 11-17.

Frings, P.J., W. Claymans, E. Jeppesen, T.L. Lauridsen, E. Struyf and D.J. Conley. 2014. Lack of steady state in the global biogeochemical Si cycle: Emerginh evidence from lake $\mathrm{Si}$ sequestration. Biogeochemistry, 117: 255-277.

Hayasaka, T., H. Fujii and K. Ishiguro. 2008. The role of silicon in preventing appressorial penetration by the rice blast fungus. Phytopathology, 98(9): 10381044.

Kamenidou, S., T.J. Cavins and S. Marek. 2009. Evaluation of silicon as a nutritional upplement for greenhouse zinnia production. Scientia Horticulturae, 119(3): 297-301.

Keeping, M.G., O.L. Kvedaras dan A.G. Bruton. 2009. Epidermal silicon in sugarcane: cultivar differences and role in resistance to sugarcane bores Eidana saccharina. Environ. Exp. Bot., 66: 54-60.

Liang, Y., Nikolic, M., Belanger, R., Gong, H., Song and A. 2015. Silicon in agriculture: From theory to practice. Springer. Amsterdam

Lindsay, W.L. 1979. Chemical equilibra in soil.John Wiley and Sons. New York

Marschner, H. 1995. Mineral Nutrition of Higher Plants.: Academic Press. San Diego.

Meyer, J.H. and M.G. Keeping. 2005. The impact of nitrogen and silicon nutrition on the resistance of sugarcane varieties to Eidana saccharina. Proc. S. Afr. Sug. Technol. As., 79: 363-367.

Munawar. 2011. Kesuburan tanah dan nutrsi tanaman. IPB Press. Bogor
Pratono, I., S. Wardhani dan D. Purwonugroho. 2013. Pengaruh teknik ekstraksi dan konsentrasi $\mathrm{HCl}$ dalam ekstraksi silika dari sekam padi untuk sintesis silika xerogel. Kimia Student Journal, 2(1): 358-364.

Refnita, G., Z. Zuki dan Y. Yusuf. 2012. Pengaruh penambahan abu terbang (fly ash) terhadap kuat tekan mortar semen tipe pcc serta analisis air laut yang digunakan untuk perendaman. Jur. Kimia. Unand., 1(1).

Sakr, N. 2016. The role of silicon (Si) in increasing plant resistance against fungal diseases. Hell. Plant Protect. J., 9(1): 1-15.

Szulc, W., B. Rutkowska, M. Hoch, E. Spychaj-Fabisiak and B. Murawska. 2015. Exchangeable silicon content of soil in a long-term fertilization experiment. Plant Soil Enviro., 61(10): 458-461.

Snyder, G.H., V.V. Martichenkov and L.E. Datnoff. 2007. Silicone in handbook of plant nutrition. CRC Taylor and Francis. New York

Summer, M.E. and M.P.W. Ferina. 1986. Phosphorus interaction with other nutrients and lime in field cropping systems. In: Stewart B.A. (eds) Advances in Soil Science. Advances in Soil Science, vol 5. Springer, New York, NY.

Van Bockhaven, J., D. De Vleesschauwer and M. Hofte. 2013. Towards establishing broad spectrum disease resistance in plants: silicon leads the way. $J$. of Exper. Bot., 64(5): 1281-1293.

Yukamgo, E. dan N.W. Yuwono. 2007. Peran silika sebagai unsur hara bermanfaat pada tanaman tebu. Jurnal Ilmu Tanah dan Lingkungan, 7(2): 103-106.

Zellner, W., J. Frantz and S. Leisner. 2011. Silicon delays Tobacco ringspot virus systemic symptoms in Nicotiana tabacum. J. of Plant Physiology, 168(15): 1866-1869. 